Original Research Paper

\title{
Pharaonic or Ottoman in Modern Egyptian Culture: Consequences of Immigration
}

\author{
${ }^{1,2}$ Dina Aly Ezzat, PhD \\ ${ }^{1}$ Department of Sociology, University of California Riverside, USA \\ ${ }^{2}$ Department of Sociology, Assiut University, Egypt
}

\author{
Article history \\ Received: 24-02-2019 \\ Revised: 16-08-2019 \\ Accepted: 08-01-2020 \\ Email: dezzat@ucr.edu
}

\begin{abstract}
It is often assumed by tourists and other visitors to Egypt that all or most aspects of Egyptian culture originated from the Pharaonic period or ancient Egyptians. This perception is, however, wrong as Egypt over the centuries experienced immigration and even occupation by outside powers who left their mark on the country. The aim or purpose of this paper was to trace the Turkish origins of modern Egyptian culture. Data for the paper were obtained through analysis of historical documents, interviews of historians, experts and other officials at the Ministry of Antiquity, visits to various sites, including famous buildings and other landmarks. It was concluded that in almost every major area of culture, including government organization, education, the courts, medicine, law and infrastructure Turkey heavily influenced Egypt. Many words used today in Egyptian Arabic are of Turkish origin. Conclusions derived were not meant to minimize Egyptian civilization, but to offer a fuller accounting of how many components of this civilization had Turkish origins.
\end{abstract}

Keywords: Culture, Egyptian Culture, Turkey, Ottormans, Immigration

\section{Introduction}

To many researchers and the thousands of tourists that visit Egypt annually and indeed many Egyptians, modern Egypt owes its cultural origins, traditions and even architecture to Ancient Egyptians. In short, many limit the beginnings of Egyptian civilization to the Pharonic age. This perspective is, however, not a full accounting of the history of Egypt, as numerous aspects of the country's past can be traced not to ancient Egyptians or to the Pharohs, but to the Turkish Ottomans, who occupied Egypt from 1516 to 1952 . Using qualitative methods, this paper shows how the Turkish Ottomans influenced the country's culture and provides numerous examples to demonstrate the debt owed by modern Egypt to the Turkish Ottomans. The cultural influences are diverse and obvious in the way Egyptians dress, eat and communicate. Therefore, the belief that all of Egypt's culture and traditions are from the Pharonic period needs correction as many of the cultural roots go back to Ottman culture (Albana, 2015).

The aim of this paper is to trace the Turkish origins of modern Egyptian culture and examine how Egyptian civilization not just in artifacts, architecture, political systems and other institutions changed during the
Ottoman rule of Egypt. I demonstrate how Turkish traditions brought by the Ottomans have affected Egypt to the present day in many areas of culture, including human behavior. The paper further investigates the effect of the Ottomans during the Ottoman caliphate on Egyptian society politically, socially and on language, customs, traditions and relationships among individuals. The paper is organized as follows: First, it briefly reviews the history of the Ottoman occupation of Egypt. Second, it proposes the behavior or deeds of Ottoman rulers and how their behavior influenced Egyptians. Third the paper proposes methods used to collect data and do the analysis. Fourth, analytic results are presented and the paper closes with a conclusion regarding past and future research.

\section{The History of the Ottomans in Egypt}

The Ottmans' obvious influence on Egypt in ancient times has clearly appeared as their interests have penetrated among the sects of the people; their residences spread among villages and cities. Egyptians and Ottmans worked side by side in the fields of work and production and in the process, Egyptains learnt how to work from foreingers and craftsmen and artisians spread in new fields, including academic. Moreover, the 
classes of workers, employees, tradesmen and professionals, who daily and directly faced not only the Egyptian people but also the social problems in Egypt are evident. Foreign invaders passed unto Egyptins their culture with all its good and evil aspects (Soliman, 1996, p. 317; Abdel-Rahim, 1967, pp. 3-6).

The relationship between Egypt and Anatolia is considered a special one due to the existence of the Ottman rule during a period known as 'the Ottoman Caliphate'. During this period, an interaction between Turkey and Egypt took place on the governmental and public levels. Although this relation was not based on equality, Egypt was under Ottman dominance in Istana. The one who represented Eqypt was the Ottman ambassador. However, after the Treaty of Lausanne the situation changed; the hereditary dynasty became that of Mohammed Ali's family but at the same time under Ottman supervision. Egypt was dominated by the Ottmans for about half a century and within that period, things changed dramatically (AbdelRahim, 1967, pp. 3-6; Al-Sheikh, 1996, p. 79).

As regards the Ottmans' condition in Eqypt, they were divided into two groups: the first group was at the top of the social pyramid in villages and regions. These were the "Beys" and "Aghas" and some of them took up positions of governing and administration. Their mission was to execute central government policies in the capital which focused on confirming the central authority on regions. On the other hand, the other Ottman group became professionals in other crafts other than governing and administration. They became affliated with the natives and kept holding unto traditions from the Ottman environment from which they had emigrated and influenced Egyptian culture, custom and traditions (Shalaby, 1992, p. 39).

Changes in Egyptian culture in favor of the Turkish Ottomans was greatly influenced and facilitated by Mohamed Ali and his family in Egypt, especially in Cairo and Alexandria ((FeidAllah, 2010, pp. 50-52). Who believe that the influence took place only in these two provinces. This view is however, not true as all of Egypt was completely influenced by this culture. For instance, Egyptian architecture and buildings were influenced by the Ottman structure and patterns in most Egyptian towns, especially Assiut. This is obvious from the Ottman architecture, buildings and ornaments still prevalent in Assiut.

In the days of Mohamed Ali basha, Assiut flourished, developed a lot and it was named during his reign as 'the Directorate of First Half, Upper Egypt'. It received great attention and care from Al-basha and it was the headquarter of his sons for about six years. He established in it luxurious buildings, whose effects are still seen today. Al Majzoub's spans in Assuit were built during his rule. Moreover, he built the first school in the governorate which exists today in a building that contains teachers' school and overlooks the Nile (FeidAllah, 2010, pp. 50-52).

Egypt was influenced a lot by the Ottmans in administrative and urban planning. For example, in the days of Mohamed Ali, Egypt was divided into seven directorates. Mohamed Ali was the first to name Egypt's administrative divisions as governorates (as they are known today) and the first to call its heads as administrators (FeidAllah, 2010, pp. 50-52).

The Ottmans expanded architecture, commerce, literature, education and law all over Egypt. For example, there is Soliman Basha Mosque in Bollaq, Cairo, Sedi Saria Mosque at the castle at the corner of Al-Sheikh Mohamed Al-Kaaky. The silversmiths 'Amer's market' is one of Egypt's oldest markets in which precious metals such as gold, silver, pearl and braize are sold and there is Kharsouf Basha's stationary which was built by Kharsouf basha for the education of children. Ali basha also built a great commercial agency with buildings in Fowa village and developed $\mathrm{Al}$-sebaa, spanning the area of Al-Sayeda Zeinb in Cairo. He also developed greatly the judicial system (Al-Sediki, 2005, pp. 104-107, p. 163).

During the Ottman Caliphate, Architect Senan Basha, who was commissioned by Al-Sultan Soliman, built 81 big mosques, 52 small mosques, 55 schools, 7 institutes for the study of the Quran, 3 hospitals, a printing house for memorizing the Quran, 7 bridges, 33 palaces, 18 inns, 5 museums, 33 bathhouses and 19 mausoleums or domes. During the reign of Al-Sultan Baized the second public transport improved which aided building construction and development. The Ottmans built many mosques with lots of libraries in which they added books written in the Ottman language and lots of Islamic literature books from their Ottman Empire. The Turks paid great attention to poetry and Al-Sultan Saleem the first himself wrote a great poem (Al-Sayed, 2011, p. 184, pp. 187-188).

Despite the achievements of the Ottomans, neglect of restoration and the destruction of Turkish built structures throughout ages made many people believe that they are just ancient Egyptian buildings that have no relevance to the Ottman culture. In fact, the roots of these ornaments go back to the beginning of the $19^{\text {th }}$ century, since the Ottman Caliphate in Egypt. Mohamed Ali was one of the soldiers of the battalion sent by the Ottman Sultan to fight the French in Egypt; the French had tried to seize the country from the Ottman Caliphate. Mohamed succeeded in doing so and he and his family kept ruling Egypt till the 1952 Revolution and Abdel-Nasser's rule of Egypt (Albana, 2015).

Relatively little is known about the influence of the Ottman culture on Egyptian culture. Egypt is considered one of the most important great nations in the Middle East; therefore, this relation has had an effective influence on this area throughout the ages. The relationship between Egypt and Europe is considered special due to the existence of the Ottman Caliphate in 
Egypt (From 1516 to 1952) and during this period, an interaction between the Ottman Empire and Egypt occurred on the level of the government and people (Abdel-Rahim Moustafa, 1967, pp. 3-8).

This study shows the Ottman part in Egyptian culture in order to help researchers understand Ottoman cultural roots in Egyptian society. It also helps and benefits the global community to have a more accurate comprehension of the historical origins of modern Egypt. The study analyzes Ottman foundations of Egyptian culture including customs, traditions, values, thoughts, practices and lifestyles by classifying the cultural parts of Egyptian culture (such as language, cooking methods, trade, crafts, working and employment style, decoration, makeup, games, entertainment, clothes, accessories, home, cooking etc.) and showing systematically how they originated from Turkey.

\section{Methods}

I collected the data for this qualitative study in Egypt from 2016 to 2018 inclusive and information comprised documentary analysis of historical records and interviews of officials at the Department of Antiquity. Photographs were also taken of historic sites, including musuems, bridges, mosques, ancient palaces, with official permits from the Ministry of Antiquities and the Ministry of Higher Education. Hence, the most important sources of data collection are from historical documents, previous studies and through investigation of historical records. Face-to-face interviews were also done with professors in the Department of Antiquities, Assiut University and with employees of the Ministry of Antiquities. I used descriptive and historical methods to analyze Egyptian society's relations with Turkey through the ages.

To determine reliability and validity, after identifying any artifact or document as having origins in Turkey, professors in the Department of Antiquity at Assiut University were independently asked to authenticate origins. Face validity was ensured by comparing answers from at least two professors. They were then asked to provide underlying source documents supporting their answers. Information gleaned from documents were then presented to experts at the Ministry of Antiquity in Cairo for cross validation. For major infrastructural projects, such as bridges, mosques, palaces and buildings, reliability and authentication were achieved by comparing information on plaques posted on the structures with data given by officials of the Ministry of Antiquity. In some cases, officials provided evidence based on carbon dating to show history of a structure. I then traced the historical date to determine whether of not it coincided with that time period the Ottomans were in Egypt.

\section{Findings}

I found that Qasr al-Nil as seen in Fig. 1, was the first bridge established in Cairo to connect the two banks of the Nile, where Khedive Ismail issued an order for construction in 1865 . Building the structrure commenced in 1869 by a French company and it took about three years to complete in the middle of 1871. It is a part of the famous Eltahrer squire in which Egypt had its latest revolution in 2011.

The Palace of the Dome as seen in Fig. 2, located in Cairo, is the largest palace in Egypt. It was build by Khedive Tawfiq (a Turkish king) who was born in Qasr al-Kubba in 1852. The Palace is currently used as the residenc of foreign guests and dignitaries from presidents to kings. President Abdel Fattah Al Sisi was sworn in as the eighth president of Egypt in the palace and used it as his official residence for while.

King Farouq as seen in Fig. 3, gave his first speech on May 8, 1936, from the palace, following the death of his father Fuad I.

Before the 2011 Egyptian revolution, President Hosni Mubarak received President Barack Obama at the palace and both met on the stairs shown as Fig. 4 .

In July 1872, 146 years ago, protests of the people of Alexandria escalated, after the intention of the Khedive Ismail to put a statue of his grandfather Muhamed Ali in Manshia squire in Alexandria became known. Below the first picture (left) is the statue of Muhamed Ali in Manshia squire today, but the second one is that of Muhamed Ali in Manshia scuire in 1872.

The picures below are of the two most famous mosques in Assiut Governorate as seen in Fig. 6, Upper Egypt. They were built by Turkish governors when they immigrated to and occupied Egypt. The mosques are in Assiut's historic district, often called Old Assiut.

\section{The Beginnings of the Otmman Existence in Egypt}

Given that Egypt is one of the greatest civilizations not only in the middle-east but also in the whole world and has a unique geographical location among three continents, this tempted the Ottman Caliphate to expand (Moustafa, 1993, p. 329). Throughout the ages Egypt owned special resources which led a number of great forces to conquer it and stay in it for ages such as the English, Ottman and French invaders. This lead to the appearance of strong influences of culture contact between Egypt, which had had a great civilization and the occupation nations. Therefore, the shape of Egyptian culture changed into a composite cultural form interrelated with the Ottman culture (Moustafa, 1993).

The Ottmans officially invaded Cairo in 1517 after a conflict and battle that lasted between Al-Mamluk state and the Ottman Caliphs in the Battle of Raidaniyah. Since then, Egypt became the best ... that decorates the turban of the Ottman Sultan (Yehia, 1981, p. 403). 


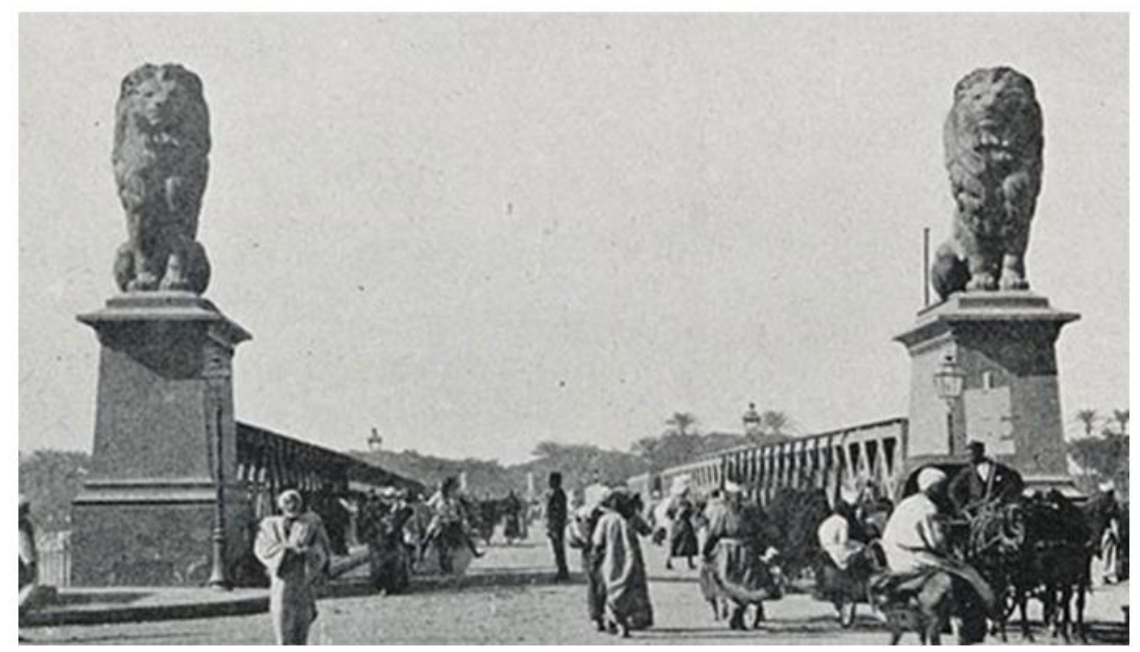

Fig. 1: Qasr al-Nil, 1869-1871
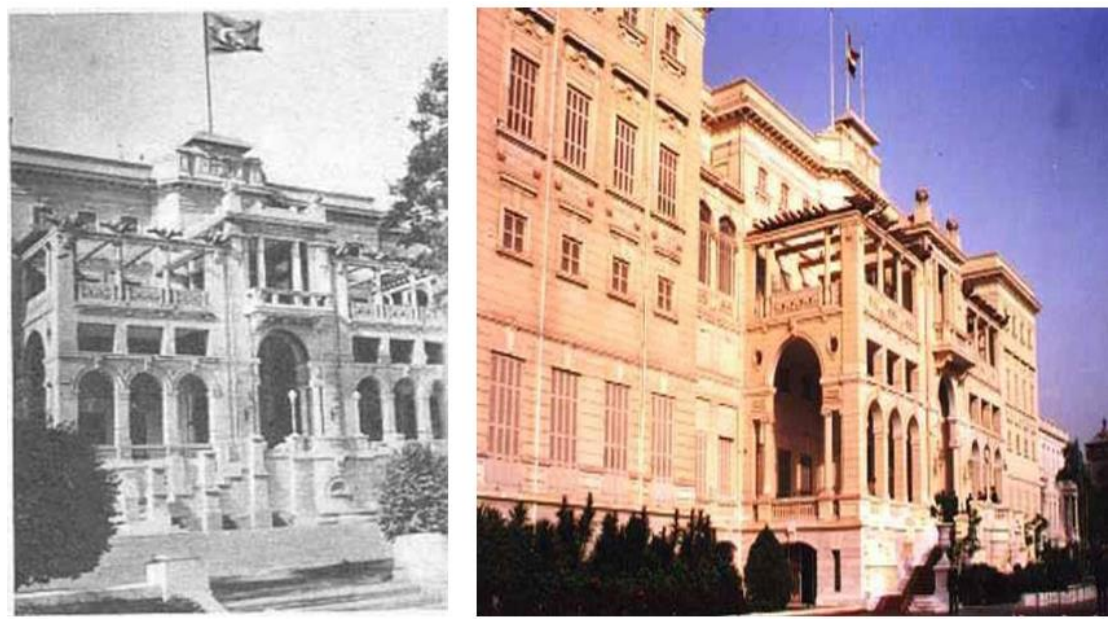

Fig. 2: The Palace of the Dome then (With the Turkish flag, left) and now (With the Egyptian flag, right)

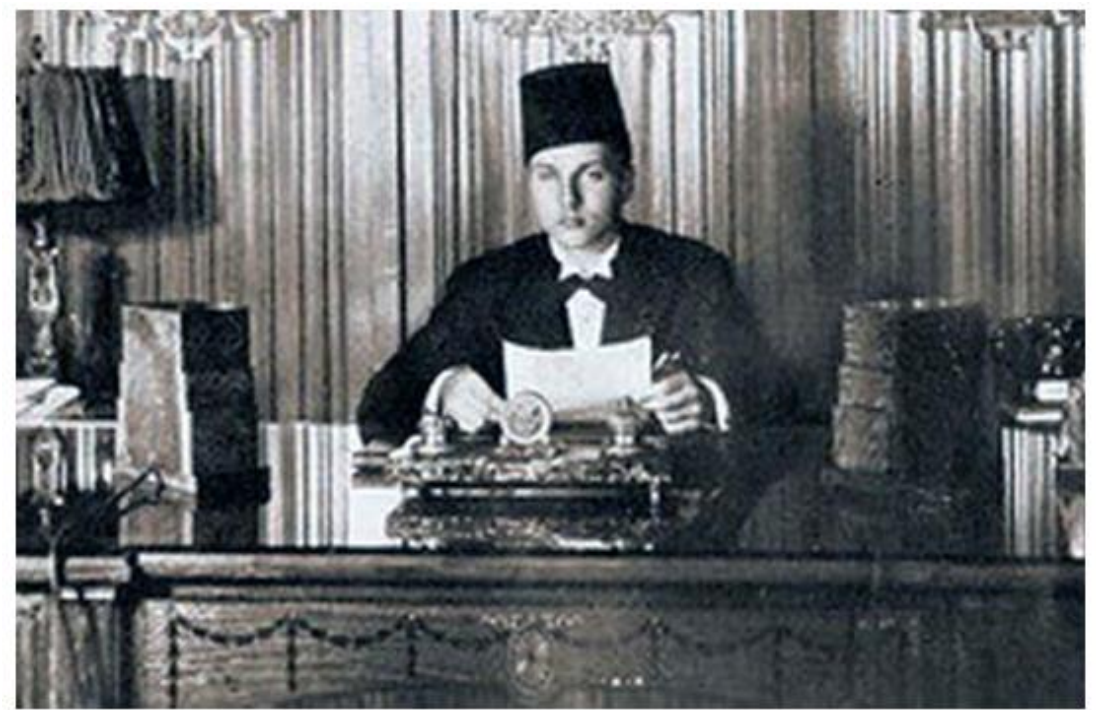

Fig. 3: King Farouq, May 8, 1936 


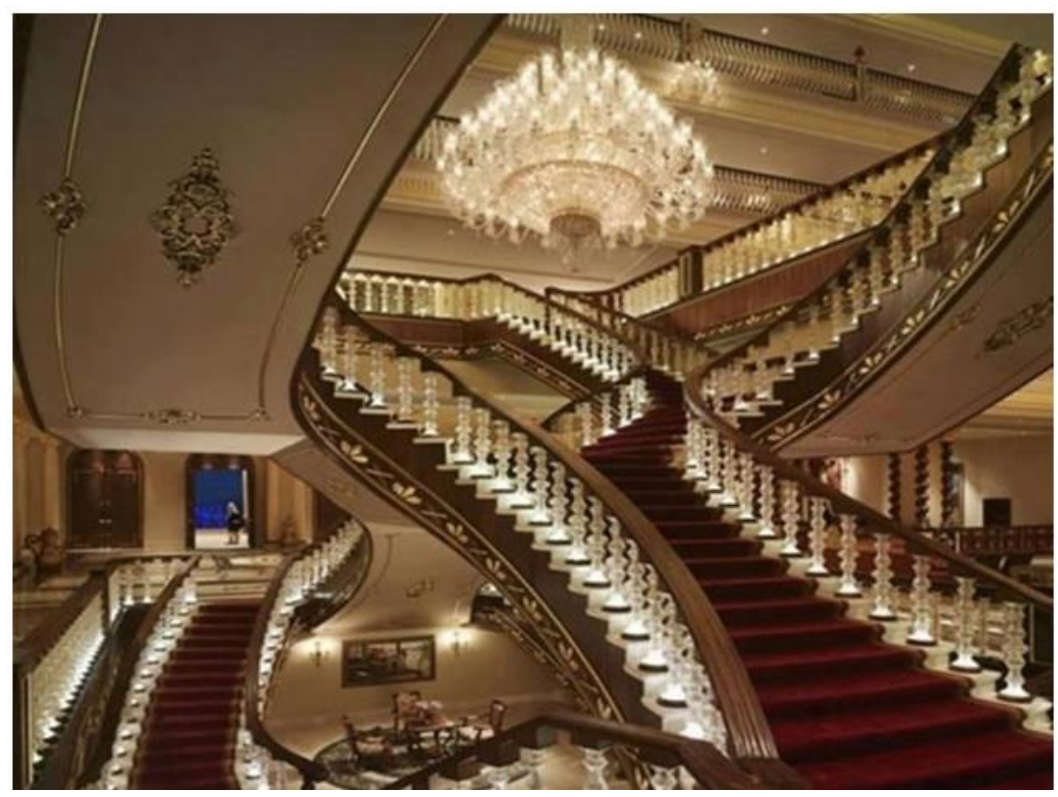

Fig. 4: The Staircase in the Palace of the Dome

There is more than one reason for the Ottman's invasion of Egypt including the adjacency of the two countries and the Ottman's conquest of Europe became fulfilled so they wanted to head west to perform their religious duty, to face the countries of Purism and Shiism and to protect the Islamic holies in Al-Hejaz from the Portugese especially after the weakness of Al-Mamluks in Egypt. They conquered it after the defeat of Sultan Qansawi Al -Ghouri in the battle of Marg Dabiq, presently in northern Suria (Abdel-Razeq Eissa, 1997, pp. 66-67).

\section{The Ottman's Settlement in Egypt}

The Ottman conquest aimed at keeping the dominant situation in Egypt as long as the Egyptians showed obedience, paid money for the capital of Istanbul and prayed for the Sultan in mosques as a sign of their loyality. The Ottmans deliberately aimed at securing these conditions to make balance between authorities in ruling the new state (Ahmed Zakaria, 2002, p. 89).

Egypt became a client state to the Ottman state under Sultan Saleem the first, who kept a number of AlMamluk forces to help him in the administrative stability of countries given that they had experience in management and to take advantage of their military power in overcoming the rebellions of Bedouins, Anchors and Sahaibeh in Egypt as these groups were experienced in carrying out revolts.

All aspects of civilization between Egypt and Turkey were exchanged such as manufactures, technicians and scientists. Egypt became dependent on the Ottman industry and the Ottmans lived in all the villages and cities of Egypt which facilitated the Ottman's ability to influence the culture of the Egyptian people (Essa, 1997, pp. 5-12 and Al-Sayed, 2000, p. 40). What is meant here is cultural influence. Culture is that compound that includes knowledge, beliefs, Art, ethics, law, customs, abilities and other traditions that a man acquires as a member of the society (Moustafa, 2009, p. 86). The Ottman culture of art and crafts prevailed in Egypt particularly because there was a political motive behind spreading the Ottman culture in Egypt. The Ottman Caliphate wanted to dye its states with a Turkish dye in order to confirm their political subordination to it (Mohamed, 1973, p. 28).

The Ottmans stuck to literature, poetry and science in which they distinguished themselves and spread it among their conquered states. They knew songs and and fairytales. Folk tales and poetic molds prevailed in the Ottman Anadol accent. For example, the poems of Youness Emra and Bazegy Oghlo spread widely especially in the main centers of the Ottman Caliphate (Al-Sayed, 2011, p. 183).

Al-Sultan Soliman Al-Kanony, who was entitled ' servant of the two Holy Mosques, Mecca and Al Madinah', became a servant who looks after Mecca, Al Madinah and the Muslim interests (Barakat, 2000, p. 18). He also helped them to mix with Egyptians as they belonged to the Islamic religion as did most of the Egyptian population at that time. In the reign of Prince Othman and in an early stage, the religious, military and political situation of the Ottmans was determined. This prince embraced Islam and the Ottmans followed him as their religion was unknown before that time (Al-Shenawy, 1980 , p. 36; Mohamed, 1973, p. 12). Even in the $19^{\text {th }}$ century the Ottmans considered themselves Muslims. 
Islam and the Ottman language were the two main conditions required to enjoy authority, social status and uniqueness regardless of the orgin and roots of its embracer or his/her relative position. What is more important is that he made the Ottman language written in Arabic letters as an official language for the transactions of all the states of the Ottman Caliphate including Egypt. This is one of the general aims of the Ottmans with the gradual fusion of the Ottman states which led to a strong opportunities of commercial and industrial activity (Moustafa, 1993, pp. 32-33). Egypt was influenced by the idea of clergymen's selection of tasks.

Egypt was influenced by the idea of task identification by clergymen. The Mufti was assigned religious positions in the capital whereas in the states, judges performed these tasks. In mosques, the Iman's task was restricted to praying with the people and preaching to them in Friday sermons. Al-Sultan Mohamed the fifth was the one who arranged religious jobs in a private decree and conditioned the learning of clergymen at religious schools in order to work at mosques. The number of clergymen reached 90,000 students during the reign of Mourad the second. Then, students were alloed to choose either to teach or work in the judiciary or religious work (Al-Sayed, 2011, p. 180).

Scientists and teachers were highly respected. Every city had its own college that taught language, engeneering and astronomy. In addition, the Ottman caliphate dedicated its interest in practical training for war and general life affairs. General Service in palaces represented a school for the princes of ruling families, Ottman youth and tough boys from the public (Moustafa, 1993, p. 41).

The Ottman rule in Egypt remained for the elite and aristocatic class of Ottmans, Armenians and Circassians, who worked in the service of the Ottman caliphate and the family of the Albanian Mohamed Ali Basha rulers of Egypt in the name of the Turkish. The Turkish language became that of culture, government, divans, classy communities, great families (Moustafa, 1993, pp: 106-122, 42). Books in the different fields of science appeared during the Ottman caliphate and all its states. Preaching books appeared in the Ottman language so that the reading public could look into them. Ottman scientists wrote history using the Ottman language (Al-Sayed, 2011, p.181).

Egyptians would have talked in the Ottman language and gone out of the Arabic frame if it wasn't for the existence of Islamic mosques and institutions that taught the Arabic language and sciences of religion in Arabic and schools that insisted on memorizing The Quran and taught Arabic principles (Moustafa, 1993, pp. 106-112; Mohamed, 1973, pp. 11-17).

Approaching the end of the Ottman rule, the suffering of the Egyptian population increased and spread due to injustice and neglicance in favor of the Ottman caliphate in Turkey. At that time, administrative corruption in the ruling system, lack of security, regression of economic conditions and heavy taxes imposed on Egyptians spread, in addition to the treatment of Egyptians as slaves unlike the ruling Ottman class which was always above the law (Al-Khashab et al., 1990, p.59; prepared by AlShishtawy and Al-Melwany, 1999, pp. 3-8). In the 23 July revolution in 1952 Egyptians rose to disobey the family of Mohamed Ali, stopped talking in the Ottman language, cancelled titles, becoming free from all that was Turkish and took the remaining treasures that the Ottmans hasd acquired from the Egyptian people. In this way, the cultural Ottman emergence that invaded Egypt in all fields and arts stopped (Abu-Ouf, 2011; Mekki, 2005, pp. 1-3). However, remnants of Ottoman occupation remained due to excavations.

Archaeologists also found discontinuity of evidence of common Egyptian names used before the time of the Ottmans and their replacement by Ottman names such as vegitables, beans, fruit, craft work, education, army, police and by the names of streets, squares, animals and birds. In this way, it became impossible to escape from the effects of the Ottman language by Egyptians. The Ottman language removed a lot from the roots of Arabic language. Egyptian language was replaced and Arabic conjugation was conducted on Ottman words (AlDemerdash, 1989; Barakat, 2000). The Ottman use of Ottman language was not only because it was the language of soldiers and government but also because it was considered the most important means for communication among countries that came under the cover of Ottman rule in communication, treatment, medicine, pharmacy, police, food, drinks, post, transport, in all aspects of social, political, artistic and public life and in all fields of social and cultural life (Moustafa, 1993, p. 42). The Ottmans left Egyptians ability to speak an unfluent Turkish language in Egypt, to live their life patterns and to unconsciously use Ottoman culture by their modernization of Egyptian society. Cross-cultural pollination, sending scientific missions and scientific cultural exchange among Egyptians, Ottman states and Europe became prevalent (Barakat, 2000; Elwan 2015; Tossoun, 1935).

The Egyptians, impressed by the Ottmans' life, civilization and lifestyle, imitated the Ottmans and consequently, Egypt's connection with them increased. Egyptians were influenced by them in their private life, behaviors, their view of life and the value of things around them changed. They imitated them in everything in their material and moral life. In time, most of the materialistic life of Egyptians became purely Turkish (Soliman, 1996, p. 338).

It was natural for the Ottman invasion of Egypt to be accompanied by an effect on the field of language. This was obvious in the foundational texts of Ottman Buildings in Egypt (Nassef amd Tadmery, 2013; Barakat, 2000). Below I present findings on how 
language used by the Ottomans found their way into current Egyptian language in various areas of culture. A summary of Ottoman (Turkish) words and concepts and how they are used today in Egypt is presented in Table 1.

Table 1: Related Turkish Word Used in Egyptian Slang Languge in Egypt

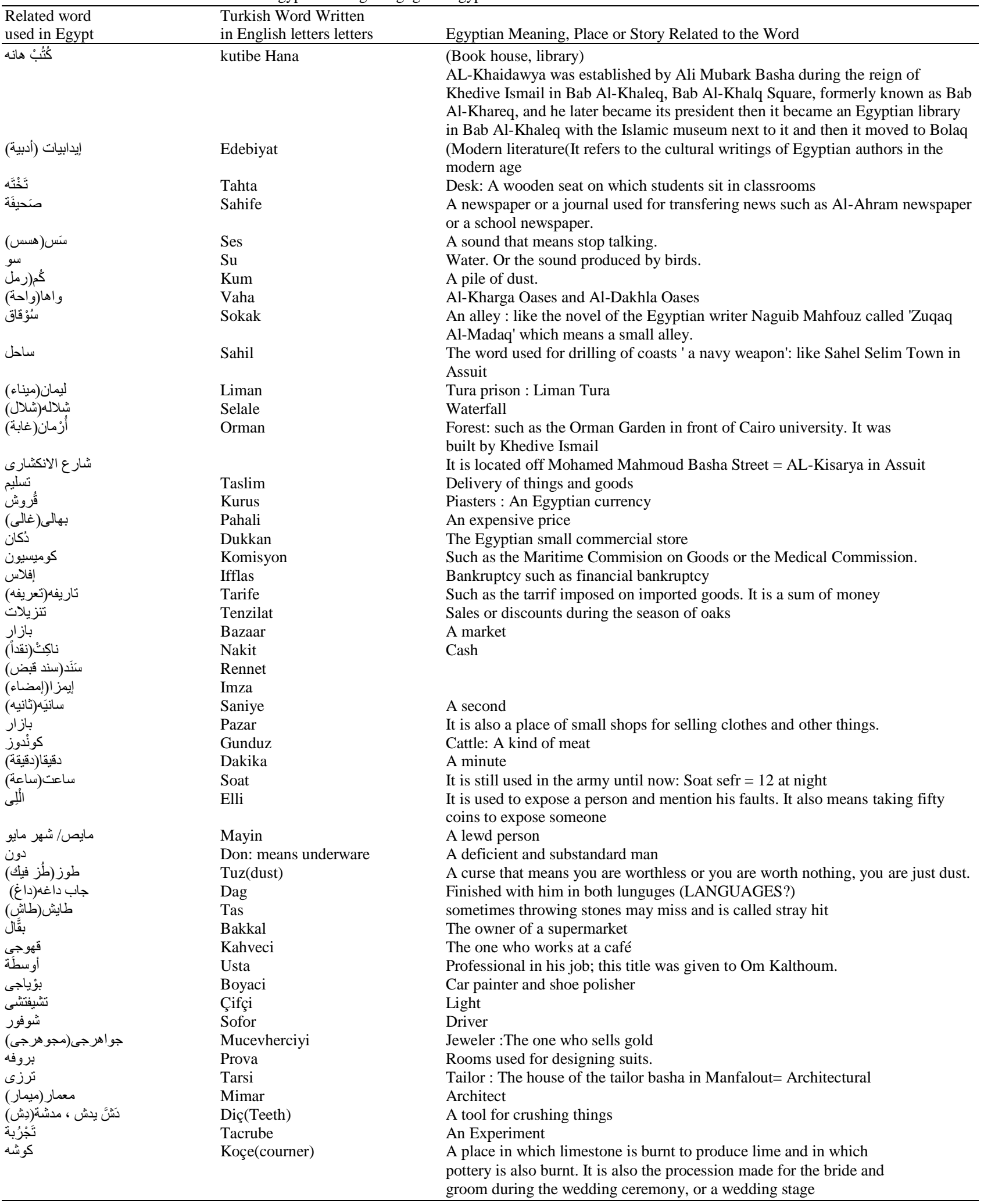




\section{Table 1: Continue}

\begin{tabular}{|c|c|c|}
\hline بوش & $\mathrm{Baç}$ & Fixing a setscrew \\
\hline بويا & Boya & Wall paint \\
\hline مقاص(مقص) & Makas & Scissors \\
\hline فابريقا & Fabrika & Factory \\
\hline هاى هاى(اهلا) & Hay Hay & Gladly \\
\hline الهاى باى & & People on Top \\
\hline د دوْرو & Dogru(straight) & A straightforward man \\
\hline شَتَنْ & Sey & Somthing \\
\hline فقط & Fakat & Only \\
\hline حاظر & Hazir & Ready or Ok \\
\hline مشغول & Masgul & Busy \\
\hline خوش & Haç & $\begin{array}{l}\text { Come in : A neighbourhood in Ghouri in Cairo between Ghouri Mosque and Al- } \\
\text { Rome neighbourhood }\end{array}$ \\
\hline ياو اش(على مهلك) & Yawas & Slow down \\
\hline بوز & Buz & To go into a sulk \\
\hline 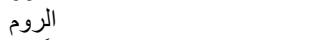 & rum & The Romans : Known in the Ottman custome as the Greeks \\
\hline 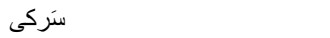 & Serge & In which the names of employees sign their names for attendance and departure \\
\hline وَزيفَه & Wezife & A job \\
\hline نووبتجى & Nowbetçi & A person on duty \\
\hline خان (دار الامير الخليلي) & Han & $\begin{array}{l}\text { A prince, a Turkish title for the princes of Turkish tribes. This titled was } \\
\text { introduced into Egypt and Islamic world through the Ottmans as it was a title for } \\
\text { their Sultans }\end{array}$ \\
\hline مقبوظو (القبض) & Makbuzu & Receiving salaries \\
\hline علاوَسى(علاوة) & Ilewasi & An allowance \\
\hline مرندس & Muhendis & An engineer \\
\hline صناديق & Snadik & A box \\
\hline مَوْسِمِ(فصل) & Mevsim & \\
\hline دولتلو(دولتلو باشا او صاحب الدولة) & Devletlu & An honorable man \\
\hline خِزم & Kizim & Short \\
\hline حفيف & Hafif & Light :Someone who is unable to hide secrets \\
\hline أسمر & Esmer & Brown skin \\
\hline أسود(قَر ا) & Kara & Black \\
\hline أكابر (كيبار ) & Kibar & Greatest \\
\hline سَوْدا(كمرض السودة) & Seyda & A whim for love \\
\hline مقبا(مُقَبَبْ) & Kaba & big \\
\hline سيِّدِ (بَتْ) & Bay & Master: Lik, mister Ahmed \\
\hline سيدة(خانم) & Hanim & Hanim or a great woman \\
\hline سَيَّد (أفندى) & Effendi & Master \\
\hline قِصةُ قِصبر) & Kisa & Incomplete or despicable man \\
\hline سيء و قبيحِ(درْدى) & Derdi & $\begin{array}{l}\text { Bad or ugly: It is the substance that comes out of the mouth of the } \\
\text { deceased person who is rotten }\end{array}$ \\
\hline 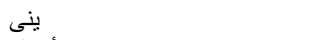 & Yeni & The name 'Yeni' or new \\
\hline إنجى (أنجَة) & Ince & $\begin{array}{l}\text { Girl name means soft: There is Inga Hanim Mosque in cairo near Rawd Al Faraj } \\
\text { Fruit Market (formerly) }\end{array}$ \\
\hline نازيك & Nazik & A girl name means nice \\
\hline جواز سفر (باسبورت) & Pasaport & The public who travel to Al-Hijaz for pilgrimage called it Pasaport \\
\hline إثشارة(إثارَت) & Isaret & A signal \\
\hline طائرة(طيارة) & Tayyare & An airlplain (do you mean air plane) \\
\hline كلاكُسون & Klakson & Car beep \\
\hline مسافَة & Masafe & Distance \\
\hline 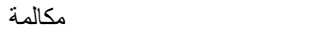 & Mukaleme & A call \\
\hline بابور البحر(فابور) & Vapour & A ship \\
\hline مَواب & Cuvap & A letter \\
\hline تَلْكر اف & Telgraf & A telegraph \\
\hline 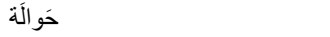 & Havale & Postal order for sending money \\
\hline 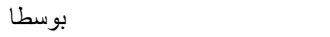 & Posta & Post \\
\hline 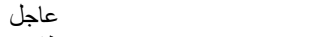 & Acil & Urgent \\
\hline بوسطاجى & Postaci & A postman \\
\hline ظرف & Zarf & An envelope \\
\hline مكتوب & Maktup & Letters \\
\hline بلبل(بُولْبُول) & Bulbul & Nightingale \\
\hline ل قوش & Kuç & A previous governor in Egypt \\
\hline طاووس & Tauus & A peacock \\
\hline 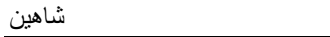 & Sahin & Hawk \\
\hline
\end{tabular}


Table 1: Continue

\begin{tabular}{|c|c|c|}
\hline سَرْجَة & Serçe & A bird: Al-Zarjah quarter off Al-Bakly street in Al-Khalifa department, Cairo \\
\hline داملا & Damla & A dot \\
\hline دبوس(طوْبوز) & Topuz & A pin \\
\hline مبودرا & Pudra & Powder \\
\hline فرشاه(فِرجا) & Firça & Brush \\
\hline معجون(موجونو) & Macunu & Paste \\
\hline 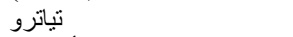 & Teatro & A theatre \\
\hline أرتيست & Artist & An actor \\
\hline سجارة(سيكار ا) & Sigara & Cigarette \\
\hline شُرنجِ(سَطْرَنْجَ) & Sataraç & Chess \\
\hline ن & Kulup & A lyrical club \\
\hline \multicolumn{3}{|l|}{ بوتن } \\
\hline بلوز بل & Bluz & A blouse \\
\hline 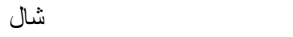 & Sal & Shawl \\
\hline كر افات & Gravat & A neck tie \\
\hline روب & Roab & A robe \\
\hline تنتلى & Tenteneli & Tantella \\
\hline كنار & Kenar & A side \\
\hline قماش & Kumaç & Cloth \\
\hline كتن(كِنَّان) & Keten & Linen \\
\hline بانطلون & Pantaloon & Trousers \\
\hline بيجاما & Pajama & Pajamas \\
\hline جاكيت & Ceket & Jacket \\
\hline جور ابلر (جوارب جمع جورب) & Çoraplar & Socks \\
\hline دوكمه(زر) & Dugme & A button \\
\hline كمر & Kemer & A belt \\
\hline أشارب & Eçarp & Scarf \\
\hline 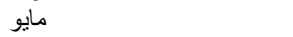 & Mayo & Swimming suit \\
\hline 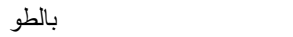 & Palto & Coat \\
\hline منديل & Mendil & Napkin \\
\hline جيب & Cap & Skirt \\
\hline لانيو (بنيو) & Lanyo & Bath tub \\
\hline 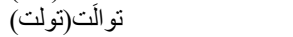 & Tuvalet & Toilet \\
\hline جكمجية(شكمجية) & Çekmeceye & A case for keeping jewelry \\
\hline كريستال & Kristal & Crystal \\
\hline صوبا اب & Soba & Soba for planting :Plant pot \\
\hline دووار(دوار العائلة) & Duvar(wall) & A place for weddings in the villages of Upper Egypt \\
\hline حصيرة(حصير) & Hasir & A straw mat \\
\hline تتس طاو لا (طاول) & Tavla & Tennis table \\
\hline كوشة(طوشه) & Kaçe & Kace is something on which the bride and groom sit \\
\hline سَبَتْت & Sepet & A basket made from the forest slices \\
\hline غرفة المسافر خانه(مِسافِر) & Misafir & Guests room \\
\hline 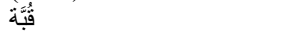 & Kubbe & The presidential palace in Hadaik Al-Kubba, Cairo. \\
\hline سَر ایى(السر اية) & Sary & There is a kind of bread called Al-sary bread \\
\hline قنديل & Kandil & A lamp \\
\hline لمبا & Lamba & A lamp \\
\hline قَنَبَّة(كنبة) & Kanape & A couch \\
\hline بَردَه(البردة او ستارةة) & Parde & The prophet's praise, peace be upon him, to Al-Bosiry \\
\hline أودا(أوضة) & Ada & A room \\
\hline أودباشىى(رئيس الغرفة) & & $\begin{array}{l}\text { The international poet, Abdullah Al-Nadeem, performed this role inthe days } \\
\text { when he hid from the Arab revolution }\end{array}$ \\
\hline بطانية & Battaniye & Blanket \\
\hline دكثْتِير (بشكير) & Degisitir & A bathrobe \\
\hline 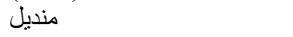 & Mendil & Napkin \\
\hline صفرة بشكيرى(فوطة سفرة) & safra beçkiri & Table napkin \\
\hline 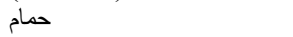 & Hamam & Bathroom \\
\hline بشكير & Peçkir & Hand towel \\
\hline موبيليا & Mobilya & Furniture \\
\hline 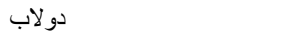 & Dolap & Closet \\
\hline سلطا(سلطة) & Salata & Things are confused \\
\hline طورشو (طرشى مخلل) & Turçu & Pickle \\
\hline طحين خلو اسى & tahin helvasi & Halvah \\
\hline جويرمَة (شاورمهة) & Cevirme & Shawrma \\
\hline طَحين(طحينة) & Tahin & Tahina \\
\hline
\end{tabular}


Table 1: Continue

\begin{tabular}{|c|c|c|}
\hline كِدا(غذاء) & Gida & Launch \\
\hline كَ كوفتَتَّه & Kofte & $\begin{array}{l}\text { A rissole wrapped in a tarab, Tarab }=\text { fatty tissue covering the stomach and } \\
\text { intestines }\end{array}$ \\
\hline شيش كباب & Çiçkebabi & Grilled meat \\
\hline بوفتاك & Buftek & Beafsteak \\
\hline ساردكليا(سردين) & Sardalye & Sardine \\
\hline شيش طاووق & Sistavuk & Shish Taouk \\
\hline تافوق(شيش طاووق) & Tavuk & Chicken \\
\hline يخنى & Yahni & Stew \\
\hline بسكويت & Biskuvit & Biscuits \\
\hline تون(تونه) & Ton & Tuna \\
\hline طازه & Taze & Fresh \\
\hline كباب & Kabah & Kebab \\
\hline كفته & Kofte & Rissole \\
\hline أوَّقا(أوقية) & okka & $\begin{array}{l}\text { An ounce and pound scale systems which are abolished and replaced by Kilo and } \\
\text { its units }\end{array}$ \\
\hline بزليه(بازيلاء) & Bezelye & Peas \\
\hline لوبيا & Lubyea & Green bean \\
\hline فاصوليا & Fasulye & Beans \\
\hline فستق & Fistic & Peanut \\
\hline باقلا(فول) & Bakla & Leguminous \\
\hline فِندِقِ(بندق) & Findik & Nuts \\
\hline بانجار (بنجر) & Pancar & Beet \\
\hline باتلجان(باذنجان) & Patlican & Aubergine \\
\hline باميا(بامية) & Bamya & Okra \\
\hline طوماطس(طماطم) & Domates & Tomatoes \\
\hline بطاطس & Patates & Potatoes \\
\hline خيار & Hiyar & Cucumber \\
\hline إسبَتاق(سبانخ) & Ispanak & Spinach \\
\hline قرنا بَهار (قرنبيط) & Karnabahar & Cauliflower \\
\hline ل بابا & Baba & Father \\
\hline آننه(أم) & Anne & Mother \\
\hline دَدَه(جد) & Dede & Grandfather \\
\hline آنَّة (جده) & Anne & Grandmother \\
\hline بابا آنَّةَّة جده الام) & anne anne & A mother's grandmother \\
\hline جنستَن(الجنس البشرى) & Cinsten & A human race \\
\hline تَتَزْهَ & Teyze & Aunt \\
\hline أوغلى(إين) & Oglu & There is Laz Ogli Square in Cairo in Garden City neighborhood \\
\hline طورون(طور ان شاه)( حفيد) & Torun & Grandson of the king \\
\hline كنج(شاب) & Genç & A brilliant and great man \\
\hline تسرَرَتْ & Servet & Wealth \\
\hline زريف(ظريف) & Zarif & Cute \\
\hline ينى & Yeni & New \\
\hline بَتَبِنجى(بشندى) & Baçinci & A person's name \\
\hline نانه(نعناع) & Nane & Mint \\
\hline نار(جُلنار) & Nar & Gelnar is a girl's name \\
\hline 'نازيك & Nazik & Nazik is a girl's name \\
\hline خانم(سيدة) & Hanim & Hanim is a girl's name \\
\hline 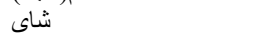 & Cay & Tea \\
\hline كاهفِه(قهوة) ك كان & Kahve & Coffee \\
\hline دُوْندرُ ما(دندورما/ بوظه) & Dondurma & Ice cream \\
\hline بيره (الييرة) & Pire(flea) & A flea as it contains small crumbs that look like fleas \\
\hline شيشه & Sise & Used for smoking moselle at cafes \\
\hline ليموناده(ليماناطا) & Limonata & Lemonade \\
\hline كاكاو & Kakao & Cacao \\
\hline تتجرة & Tencere & A ban that enlarges from down to up \\
\hline إبريق & Ibrik & Tea pot \\
\hline بهار & Bahar & Spices \\
\hline بج بطنه بالسكين(بجاق) & Biçak(knife) & Cut his stomach open with a knife \\
\hline صنابون & Sabun & Soap \\
\hline خَمور & Hanur & Yeast= baking the dough \\
\hline فِرِن & Firin & Oven \\
\hline فرشه(فرجا) & Firça & Furniture \\
\hline طاسة(طاس) & Tas & Frying pan \\
\hline ليفة(ليف) & Lif & Sponge \\
\hline ملقاط(ماشـا) & Maça & $\begin{array}{l}\text { A tweezer used for holding fire and it is used in cafes to put fire on mosele stones } \\
\text { for smoking }\end{array}$ \\
\hline 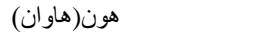 & Havan & A hun used in the kitchen to smash items such as peper \\
\hline
\end{tabular}


Table 1: Continue

Tab

سكر (شكر)

مار غارين

كبريت

فنجان

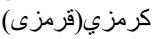

ماوى(البطيخة الماوية) - مرئ)

كستاني(كستنائى)

بأمبي( لوني) (لون)

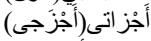

أجزخانة(أجزخانة)

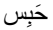

مأمور (مأمور المركزٍ)

كمُروك (جمرك المرك)

أمانات

بوليصى(بوليس)

مركزى (بولى

محكمة

الدستور

الشمشم

Seker

Margarine

Kibrit

Fincan

Kirmizi

Mavi

Kestane

Pembe

Eczaci

Eczahane

Hapis

Memuru

Gumruk

Emanet

Olis

Merkezi

Mahkeme

Dustur

Sisme

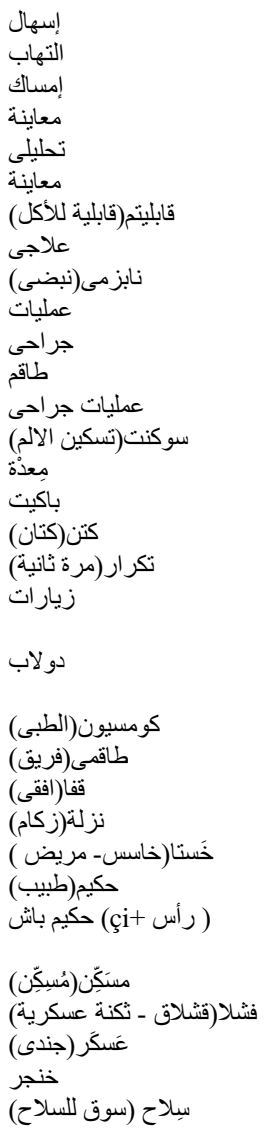

Ishal

Iltihabi

Imsak

Muayene

Tahlili

tili muayene

Kabliiyetim

Ilaci

Nabzi

Ameliyat

Gerakir

Takim

ameliyat gerakir

Sukunet

Mide

Paket

Keten

Tekrar

Ziyaret

Dolap

cotton

Kmomisyon

Takimi

Kafa

Nezle

Hasta

Kekim

hekim baçi $=$ ba

Muskkin

Fiçla

Asker

Hançer

Silah
Plate

Sugar

Artificial margarine

Matches

A cup

Dark red

A watermelon rotten on the inside, full of water and tastes bad

Reddish-brown

Rose

Pharmacist

Pharmacy

Prison

An officer who is the head of the police department

Customs

Trusts

Police, street of the Police School at Al-Aabassiya in Cairo

Center

Court

Refers to the judge, verdict and minister. It was used as a title for Ali basha Ali Basha the honorable), it was also used by the Ottmans with the meaning of permission

A powder put in the eyes if they get infected. Shamshim horoz $=$ a parallel box with a razor on it that has a drawing of a colored cock in grey and a yellow

background. This box was sold in pharmacies. The nurse used to earn his living from putting sisme in people's eyes while saying ' Sisme drops healthy for the eye, and those who are poor get to drops for free'. The nurse used to wear a suit and a tarboosh like the tarboosh of the army soldiers and uder it he used to

wear a handkerchief on his head. In this way, people came out of their houses and get sisme for free and rarely did they pay for the nurse

Diarrhea

Inflammation

Constipation

Examination

A test

Medical examinantion

Appetite

Treatment

Pulse

Operations

Surgical

Crew

Surgery

Tranquil and calmness

Stomack

A box

Flax

Repeating medicine

A visit, visiting a patient by relatives and friends at the hospital and these visits have a daily schedule after the end of work at the hospital

A cabinet that contains medicine and medical stuff such as medical gauze and

Medical Commission or Medical Committee

Medical operations staff

Vertical

Influenza or cold or Gastroenteritis

Lost weight

Doctor

$\mathrm{Ba}$ means head and $\mathrm{Ci}$ is an additive sign that is attached to the genitive. Hekim

Baci $=$ Head of Physicians

Home

Military barracks

Soldiers

Dagger

Weapon market area $=$ at the back of Al-Refaai mosque begins the door of the vaults of Mohamed Ali and his family and this door extends along Mohamed Ali's street 'presently known as Al-Kalaa street' and intersects with Al-

Mogharblein street and continues along Mrs Safia's mosquea It is a place that sells weapons) 


\begin{tabular}{|c|c|c|}
\hline بير اق(البيرق ، بيارق - عَلْم) & Beyrak & $\begin{array}{l}\text { Sag = right or a major which is a rank that was used in the army } \\
\text { during the reign of Monarchy }\end{array}$ \\
\hline أفارن(عفارم- أحسنت) & Aferin & Well done or a praise given in the morning queue \\
\hline أفنْدِم & Efendim & Yes, Sir \\
\hline قمة ، مكان مرتفع(تبه) & Tape & A high place, firing guns at El-Remayah Square \\
\hline خستخانة(خستخانيه) & Hastahaneye & A hospital in the army during the Ottman and Monarchy Caliphate \\
\hline علاج( علاجى) & Ilaci & Treatment or medication \\
\hline تِمَلَّْ & Yemek & A type of food used in the army during the Ottman and Monarchy Caliphate \\
\hline تمام يا أفندم(تمام) & Tamam & The work that I was assigned is done, sir \\
\hline
\end{tabular}

\section{Commerce}

The Egyptians were influenced by the Ottman existence in Egypt. Considereble knowleged was passed unto the Egyptians from the world and vice-versa through journeys and openness to the Ottman existence in the world. For example, the Ottman prince of the sea, Berry Raess, wandered in the beaches of the Mediterranean Sea, described it and gathered information on Spain, Portugal and the discoveries that took place in America. In 1513, the Ottmans obtained the map of Colombus, which represents the Atlantic Ocean with America and the western beaches of Europe and Africa. They also obtained books on southern, middle America and new lands including such books as The Brightness of Light in the Darkness of Atlas Minor, the history of the universe and creatures and a book in the history of Ottman navy called The Masterpiece of Adults in Seas (Ziyada, 2010; p.29 Al-Sayed, 2011, pp.181-183).

It was customary in Egypt to consider naming streets and squares using historical names or famous buildings in which they were built or events that took place in them or the names of famous men who lived in them. The purpose of naming them is to honor the memory of prominent events or people in the history of Egypt throughout different ages. For instance, there is a number of streets named to honor the memory of Ottman families in Assiut such as:

Khedive Ismail Street, Khedive Tawfik Street (Moustafa Al-Nahhaas Al-Majzoub, formerly Railyway Street), Al-Sultan Hassan Street (Al-Khazan Street), King Al-Farouk the first street (Mohamed Ali Street and the former Prince Farouk), Queen Nazly Street (Kolta Street), Princesses Ferial Street (Al-Kanater street), Princesses Fathiya Street (extension of Thabet Street) and Abdel-Rahman Basha Al-Nes Street (Al-Nemeis). (FeidAllah, 2010, pp. 99-100)

There are some Ottman words that influenced us in our life in Egypt through the Ottmans' journeys and contact with the world including at Table 1.

\section{Clothes}

The Egyptian dressing was influenced by the that of the Ottmans as well as the names of clothes. There are lots of Egyptian clothing names that are spelt and written like the Ottman language until now. For example: Giyinmek,pijama,pantaloon, mayo, ceket, çoraplar, putin, keten, lastik çizme (Iskander, 1965, pp: 60-63) and çanta (Baqshoul, 2013, p.5).

\section{Home and Furniture}

The Egyptian home and furniture was influenced by that of the Ottmans in their conponents and names, by looking at Fig. 5. There are lots of Egyptian words that are spelt and written like the Ottman language until now. For example: salonu, ada, mobilya and soba (Iskander, 1965, pp: 69-70). Bambakaden in Al-Sewifi Street in Cairo and it is located after Moustafa Kamel Basha house. There is a path at the end of this street called the path of Om Abbas (Maps of Cairo and Giza Districts, 2017).

\section{Kitchen}

The Egyptian kitchen was influenced by lots of Ottman food in their preparation and names. There are lots of Egyptian food names that are written and spelt in the Ottman language. For example: lemon, bananas, pomegranate, cherry, yemish, soda, orange, Lemonade, coffee, foul, mint, bazly, beans, potatoes, borgol, tarsh, baklava, table, jorum, soup, kebab, sausage, oil, yemek (army food), coconut, hazelnut, peanut and tea pot (Iskander, 1965, pp: 51-63 and p. 76).

\section{The Judiciary}

The Egyptian judiciary was influenced by that of the Ottmans. Scientists were the judges of the capital and the capitals of the states then younger scientists, were assigned the judiciary. The third class judges included three ranks which were the inspector, judges and deputy judges. A judge is the one who judges, in the absence of the prosecutor, civil and criminal cases according to the Islamic law (Al-Sayed, 2011, p.178). We were influenced by some Ottman words in our judicial system in Egypt.

\section{The Army}

By looking at Table 1, Folk stories spread among the Egyptians about the army, myrters, the life of the righteous and sultans of the past ages and the champions of wars especially among farmers and soldiers during the Ottman period in Egypt. For example, the Egyptian fleet was influenced by the relationship with Turkey in identifying the technology of weapons and war. The Ottman fleet promoted the Egyptian fleet during its 
engagement with it by uniting Egypt with Turkey. For instance, Kheir AL-Din Barbarosa worked in sea piracy then he sent for Sultan Seliem the Ottman to join his fleet and the Sultan approved. This concided with the invasion of Egypt so the Sultan joined him tho his fleet and sent him a thousand Turkish soldier with their cannons and gave him permission to increase his soldiers by joining Mercenaries.
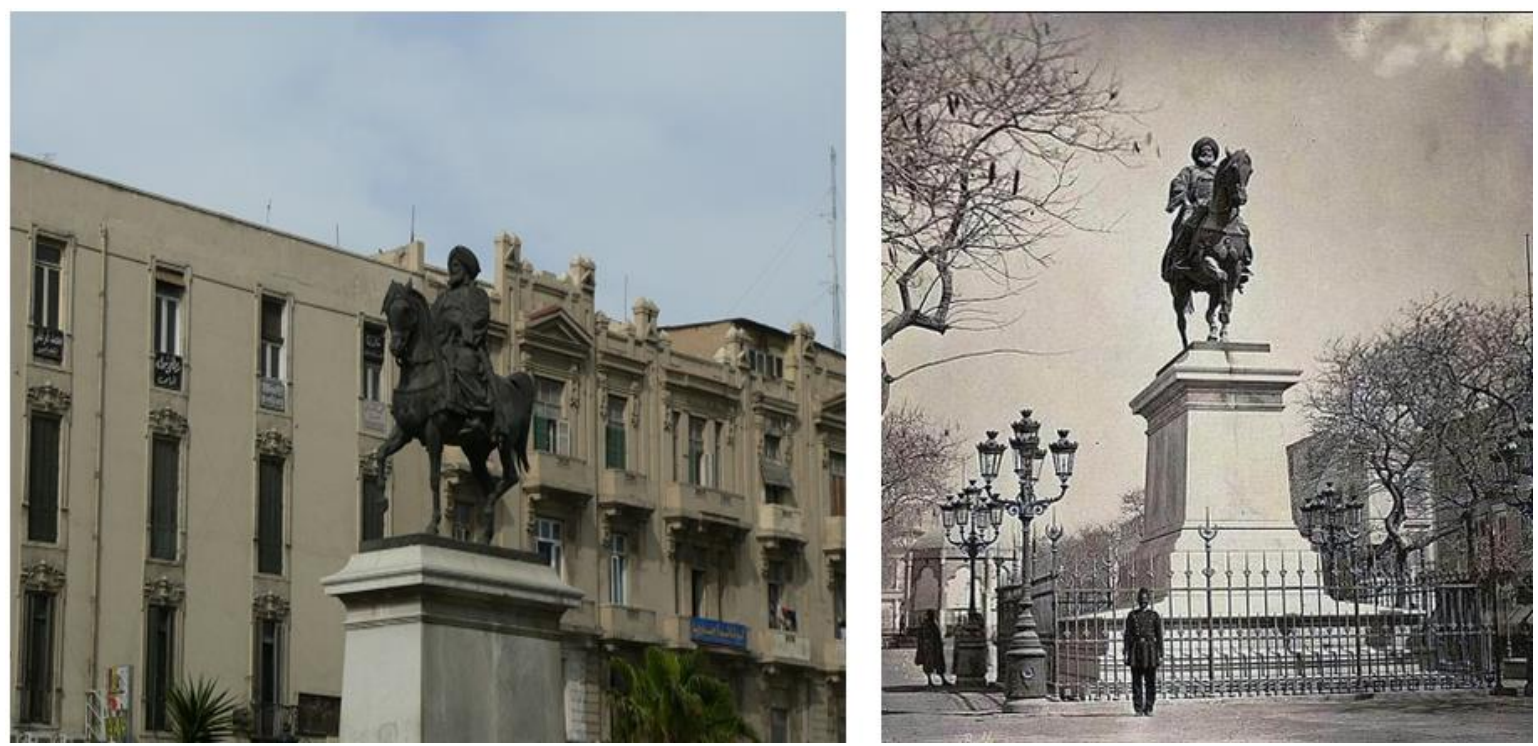

Fig. 5: Statues of Muhamed Ali in Manshia Squire in Alexandria
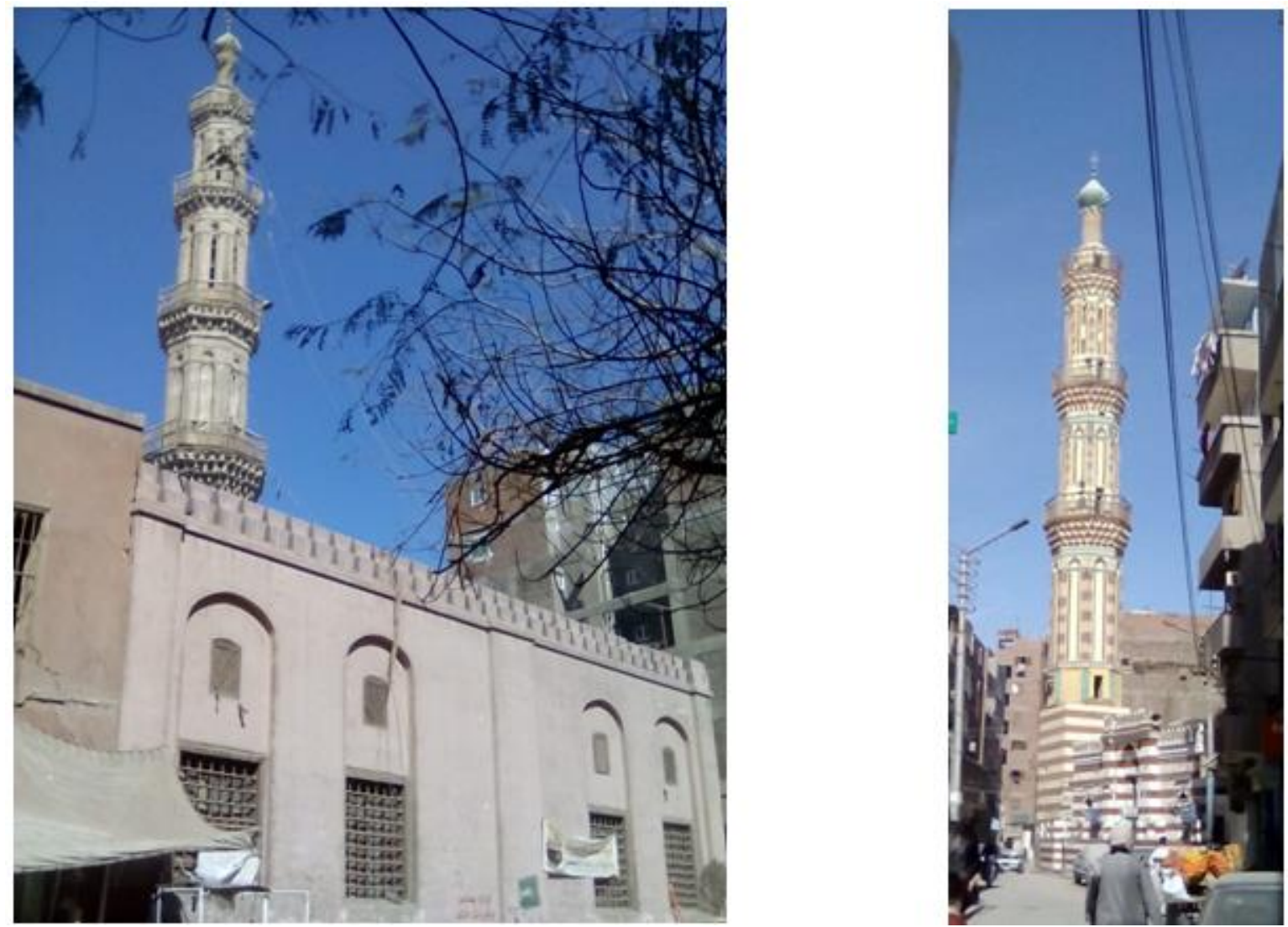

Fig. 6: El-Megahdeen Mosque (left) and El-Amawy Mosque (right) in Old Assiut 
Therefore, the fleet increased in number, developed a lot and named it the Egyptian fleet. Sultan Al-Fateh built shipyards, weapon storages at ports, institutions and weapon industries. This was a strong beginning for the fleet and Egyptian army (Al-Sayed, 2011, pp. 191-188). There are also some Ottman words that influenced us in terms of wars and invasions in Egypt including the following.

Burinci $=$ the first $=$ the army soldiers' first shift in guarding at night. A Burinci student $=$ the one who is on top of his/her class at school.

Major-general: is an honorary title like 'beh' or 'Afandy'. The holder of this title has the right to be promoted with a Sultan flag in a procession as an indication for the high status of this science. This title was given to bashas, ... and those who rule Egypt in the era of the Ottmans (Barakt, 2000, p. 153). Major-general is the greatest rank in the Egyptian army today.

Nobel: this title was used during the Ottman existence in Egypt to create honorary composite titles such as honorable princes nobilities (Barakt, 2000, p. 162).

In general, there are some words used with the same pronunciation between the Ottman and Egyptian language such as.

Sicak meaning a mountain, hikayeleri meaning short, Aawah,yanni,banzym (Baqshoul, 2013, pp. 1523) tekstil (fabrics), Piyasa (Bazzare), Hakim Bash, aga (Agha), vida (screw), galeta (rusk), Afandi (effendi), Onu al, düz (bed) and cephanelik (armory), (Soliman, 1999, pp. 35-53). Napkin means a piece of cloth, Engy which is a girl name, Gouz meaning an eye, watercress which means black, clown which is a comic doll that tells satirical stories, Ms/Mrs means a teacher or older sister in the Egyptian accent (Aaloub, 2014, pp. 22-2539-122-124-223).

It is worth mentioning established writers such as Taha Hussein who said, "We have to follow the Europeans and follow their path to become their rivals," and the writer Salama Mussa who wrote the book "Today and Tommorrow'. In this book, he pointed out that 'It is time to get used to the Europeans, wear their clothes, eat their food, use their methods in government, family, gathering, industry, agriculture, mary their sons and daughters and take from them anything that has inventions, discoveries and life systems (Soliman, 1996, p. 341).

Napkin means a piece of cloth, Engy which is a girl name, Gouz means an eye, watercress means black; clown is a comic doll that tells satirical stories, Ms/Mrs means a teacher or older sister in the Egyptian accent (Aaloub, 2014, pp. 22-25-39-122-124-223).

It is worth mentioning established writers such as Taha Hussein who said, "We have to follow the Europeans and follow their path to become their rivals," and the writer Salama Mussa who wrote the book "Today and Tommorrow'. In this book, he pointed out that 'It is time to get used to the Europeans, wear their clothes, eat their food, use their methods in government, family, gathering, industry, agriculture, mary their sons and daughters and take from them anything that has inventions, discoveries and life systems (Soliman, 1996, p. 341).

\section{Conclusion}

The Ottman Empire had a strong beginning as Prince Osman showed a great ability to establish administrative regimes. During his reign, the Ottmans truned from the ... to the stabilized administration system which helped the empire to consolidate its positions, develop rapidly into a great country and prepared it for the major role that was performed afterwards. The Ottman Caliphate was one of the countries of the kings of sects which managed to develop and become an effective Empire in the cultural roots of the whole Arab society due to its geographical location, the character of its first Sultans and its secured administrative systems (Abdel-Aziz Mohamed AlShemanwy, 1980, p. 38 Kubrily, 1967, pp. c-d).

The Ottmans liked military, equestrian sports and marriage from their kind in order to strengthen their rule and prejudice to a leader like the beduoins' prejudice to tribes. The Ottman's power began to increase one by one as they couragely fought in wars and got supported by Caliphs (Al-Sherif and Mahmoud, 2009, pp. 321-322).

The Ottman's military movements in the first stage of their history were a result of some factors which are: the religious spirit, the strict military nature, the geographical location of their empire and the political conditions of the area surrounding them. These military movements were the beginning of an active military policy. The Ottmans expanded in Asia, Europe and Africa which helped to spread their culture through their friction with new nations (Al-Shenawy, 1980, p. 43 Abdel-Aziz, 1992, pp. 60-64 Ahmed Ibrahim Al-Sherif).

\section{Limitations}

Ideally the author would have liked to visit Turkey and interview Turkish historians and other experts to obtain information at their end and determine how their history matches information provide by Egyptian scholars and texts, but cost concerns prevented the author from making such a trip. Despite the above limitations, this research provides a rather comprehensive account of the Turkish origins of Egyptian culture. It educates visitors and foreign researchers about the risks of making false assumptions about Egypt.

\section{Ethics}

This article is original and contains unpublished 
material. The corresponding author confirms that all of the other authors have read and approved the manuscript and no ethical issues involved.

\section{References}

Aaloub, A., 2014. Contemporary Persian Words, Expressions, and Structures. Egyptian International Publishing Company, Cairo.

Abdel-Aziz, O., 1992. Modern European and American history. Faculty of Arts Press, Alexandria.

Abdelkany, M., 2018. Statue of Mohammed Ali ignites revolution in Alexandria-Mohamed Abdo extinguishes sedition and khedive directed 4 black to the palace of the nile. El-Ahram, Cairo.

Abdel-Rahim, A., 1967. The relation between Egypt and turkey during the reign of khedive Ismail. Dar Al Ma'arif, Cairo.

Abu-Ouf, A.R., 2011. The novel and July revolution 1952. Issues Prospects, 6: 337-340.

Al-Araby, N., 2005. Turkish without a teacher. Dar AlShamal, Tripoli, Lebanon.

Albana, S., 2015. The architectural and decorative elements during the reign of the upper family in the light of models of facades and buildings in Assiut city. J. Studies Arab World Monuments, 14: 1177-1183.

Al-Demerdash, A.A.P., 1989. The protected pearl in the news of al-kenana and what happened in Egypt during the Mamluk state at the hands of Sanjaks, alKashaf, the seven Awjaks, the state, al-Basha till the late 1168. The French Scientific Institute for Eastern Monuments, Cairo.

Al-Khashab, I.I.S., A.A. Gamal Al-Din and E. AbuGhazy, 1990. The news of the 12th century people: The history of Mamluks in Cairo. Cairo: The Arab.

Al-Sayed, A.M., 2000. The role of Ottman garrison in the History of Egypt 1564-1609. General Egyptian Book Authority, Cairo.

Al-Sayed, M., 2011. The history and civilization of the ottman caliphate. University Youth Foundation, Alexandria.

Al-Sediki, M.I.A.A.S., 2005. The gorgeous masterpiece in the Ottman's possession of Egypt. National House Books and Documents, Cairo.

Al-Sheikh, R., 1996. Contemporary History of the Arabs. Ain Humanistic Social Studies Res., Giza.

Al-Shenawy, A.A.M., 1980. The Ottman caliphate: A maligned Islamic state. The Egyptian Anglo Library, Cairo.

Al-Sherif, A.I. and A.H.A. Mahmoud, 2009. The Islamic world. Saudi Arabia, Eastern Region: Al MUTANABI for Printing Publishing.
Al-Shishtawy, M. and Y. Al-MElwany, 1999. The masterpiece of the kings and deputies who owned Egypt. Arab Prospects, Cairo.

Baqshoul, A.R., 2013. Simplified Turkish. Abu Hedar, Oman.

Barakat, M., 2000. Ottman titles and jobs: A study of the development of titles and jobs since the Ottman invasion of Egypt until the abolishment of the Ottman caliphate through monuments, documents scripts. Dar Ghareeb, Cairo.

Egyptian Surveying Authority, 2015. Cairo.

Elwan, M.A.G., D. Gad Al-Karim and S.F. Al-Bana, 2015. The seven halls building in the mountain castle. Proceedings of the 15th Conference General Union Arab Archeologists, Jeddah and Kingdom of Morocco.

Essa, A.R. 1997. Kindergarten of the news of al Mahrousa Egypt. Library of Religious Culture, Cairo.

FeidAllah, O., 2010. Assiut City: An investigation of its Environment between the Past and the Present. General Authority Cultural Palaces, Cairo.

Hammoda, A., 2017. Black Khedive-from the zoo to the field guard. Bawaba Elfagr.

Iskander, Y., 1965. Teaching Turkish without a teacher. Midnight Press, Ankara.

Kubrily, M.F., 1967. The establishment of the Ottman caliphate: Translated by Ahmed Al-Saeed Soliman. Dar Al-Kitab Alarby Printing Publishing, Cairo.

Maps of Cairo and Giza Districts, 2017. The central agency for public mobilization and statistics.

Mekki, T., 2005. Political elite and social change: Egypt's experience 1952-1967. Dar Alam Al-Kutub for Printing, Publishing and Distributing, Cairo.

Mohamed, S.M., 1973. The mosques of Egypt and their pious worshipers. The Supreme Council for Islamic Affairs, Cairo.

Moustafa, A.A.R., 1993. The roots of Ottman history. Dar Al-Shark, Cairo.

Moustafa, G.A.R., 2009. The role of television programs in introducing local cultures: An analytical study with application on documentary movies on Sudan TV.

Nassef, E. and K. Tadmery, 2013. Learning Turkish. International Academy, Beirut, Lebanon.

Photographing a Group of Castles by the Researcher herself.

Salah, K., 2014. Palace of Dome the birthplace of the history of modern Egypt-The largest presidential palaces and the birthplace of Khedive Tawfiq. Youm Elabea.

Shalaby, H.A., 1992. Rural community during the reign of Mohamed Ali. General Egyptian Book Authority, Cairo. 
Shams, H., 1999. Comrade Araby turkey. Dar Al-Aalm Lilmalayeen, Beirut, Lebanon.

Soliman, A.A.S., 1999. Nativization of loanwords mentioned in the history of Al-Jabrti. Dar Al Ma'arif, Cairo.

Soliman, M.M., 1996. Foreigners in Egypt. Ain Humanistic Social Studies Res, Giza.

Tossoun, O., 1935. The scientific missions during the reign of Mohamed Ali then the reign of both Abbas the first and Saeed. Salah Al-Din Press, Alexandria.

Yehia, G., 1981. Europe in modern ages. General Egyptian Book Authority, Alexandria.

Zakaria, A., 2002. The Arabs and Ottman Caliphate: form Submission to Confrontation 1516-1916. Arab Egypt Printing Publishing, Cairo.

Ziyada, K., 2010. The Muslims and European modernism. The General Egyptian Book Authority, Cairo.

\section{Sources of Figures}

Fig. 1: Source: (Hammoda,

2017),

Fig. 2: Source: (Salah, 2014), https://www.youm7.com/story/2014/6/8/1712226

Fig. 3: Source: (Salah, (Salah, 2014), https://www.youm7.com/story/2014/6/8 /1712226

Fig. 4: Source: (Salah, 2014), https://www.youm7.com/story/2014/6/8/1712226

Fig. 5: Source: (Abdelkany, 2018) http://gate.ahram.org.eg/News/1977298.aspx

Fig. 6: Source: The two photos ware taken by the Author. Assiut, Egypt. 2018 